\title{
PENGARUH KUALITAS SITUS DAN PENGETAHUAN PRODUK TERHADAP SIKAP UNTUK MENDORONG NIAT BELI ONLINE DI TOKOPEDIA.COM
}

\author{
Putu Damara Juarez ${ }^{1}$ \\ Ni Wayan Sri Suprapti ${ }^{2}$ \\ ${ }^{1,2}$ Fakultas Ekonomi dan Bisnis Universitas Udayana (Unud), Bali, Indonesia \\ email: damarajuarez97@gmail.com
}

\begin{abstract}
ABSTRAK
Tujuan dari penelitian ini untuk menguji pengaruh kualitas situs dan pengetahuan produk terhadap niat beli online melalui sikap belanja online di Tokopedia.com. Sampel sebanyak 113 orang dengan metode purposive sampling. Data dianalisis dengan teknik regresi berganda dua tahap. Berdasarkan hasil analisis, ditemukan bahwa variabel kualitas situs berpengaruh positif dan signifikan terhadap sikap belanja online di Tokopedia.com, variabel pengetahuan produk berpengaruh positif dan signifikan terhadap sikap belanja online di Tokopedia.com, dan variabel sikap berpengaruh positif dan signifikan terhadap niat beli online. Saran yang dapat diberikan kepada manajemen Tokopedia.com adalah untuk mengoptimalkan tampilan situs sehingga lebih mudah digunakan oleh konsumen dan menambah informasi yang dibutuhkan oleh konsumen agar lebih lengkap dan informatif. Kata kunci : kualitas situs, pengetahuan produk, sikap, Tokopedia.com
\end{abstract}

\begin{abstract}
The purpose of this study is to examine the effect of website quality and product knowledge on the intention to online-purchasing through the attitude of online - shopping at Tokopedia.com. The sample were 113 people with purposive sampling method. Data were analyzed with two-stage multiple regression analysis. I was found that the website quality had positive and significant effect on the attitude of online shopping on Tokopedia.com, the product knowledge had positive and significant effect on the attitude of online shopping on Tokopedia.com, and the attitude had positive and significant effect on online purchasing intentions. Suggestions that can be given to Tokopedia.com management are to optimize the appearance of the website so that it is easier to use by consumers and add more information that are needed by consumers.
\end{abstract}

Keywords: website quality, product knowledge, attitude, Tokopedia.com 


\section{PENDAHULUAN}

Dalam beberapa tahun terakhir, internet dan penggunanya telah berkembang dengan pesat, baik di Indonesia maupun di seluruh dunia. Internet telah menjadi media untuk perdagangan informasi, jasa, barang hingga media sosial yang memudahkan masyarakat dan pelaku bisnis untuk berkomunikasi antara satu dengan lainnya. Salah satu jasa yang menggunakan internet adalah jasa pembelian barang secara online.

Data dari Asosiasi Penyelenggara Jasa Internaet Indonesia (APJII) Taun 2018 menunjukkan pengguna internet di Indonesia telah meningkat dari 500 ribu orang tahun 1998 hingga 143,26 juta orang tahun 2017. Pada tahun 2018, berdasarkan hasil survei Asosiasi Penyelenggara Jasa Internet Indonesia (APJII), pengguna internet di Indonesia ada sebanyak 171,17 juta jiwa. Internet telah digunakan di semua segi kehidupan, mulai dari komunikasi, surat elektronik, hingga transaksi jual beli online.

Bali yang merupakan salah satu provinsi di Indonesia dan salah satu ikon pariwisata juga mengalami pertumbuhan internet yang pesat, terutama di Denpasar, yang merupakan ibu kota provinsi. Berdasarkan hasil survei oleh Sloka Insitute (2015) tentang perilaku pengguna internet di Bali diperoleh data bahwa sebanyak 54,2 persen pengguna internet ada di Kota Denpasar, disusul oleh Kabupaten Badung sebanyak 15,7 persen.

Melihat pesatnya perkembangan internet baik di skala nasional hingga Kota Denpasar, hal ini tentu mempengaruhi aktivitas jual dan beli yang dilakukan melalui sistem online. Fenomena belanja praktis melalui situs online kini semakin menjamur di Kota Denpasar, hal ini didukung juga oleh kemunculan berbagai situs online yang mampu memenuhi segala keperluan konsumen dalam cara yang praktis, aman dan lengkap. Situs belanja yang menyediakan berbagai jenis barang dan dapat digunakan oleh berbagai produsen untuk memasarkan produknya disebut dengan e-commerce.

E-commerce adalah tempat dimana pelaku bisnis hingga UMKM dapat berjualan secara online, baik dengan cara $B 2 B$ (business to business) maupun $C 2 C$ (customer to customer). Salah satu keuntungan berjualan di e-commerce adalah penjual tidak perlu membuat situs pribadi. Penjual hanya perlu menyediakan foto produk yang menarik dan mengunggahnya dilengkapi dengan deskripsi produk yang menarik. Selanjutnya, apabila ada calon pembeli yang tertarik, pihak penjual akan diberi notifikasi oleh sistem dari e-commerce tersebut.

Saat ini e-commerce yang banyak digunakan oleh konsumen adalah Tokopedia, Lazada, Bukalapak, Shopee. Konsumen bebas mengakses e-commerce yang digunakan untuk memilih dan membeli produk-produk yang diinginkannya. Berdasar survei pendahuluan yang dilakukan terhadap 50 orang konsumen usia 1625 tahun di Kota Denpasar diperoleh data bahwa 98 persen konsumen sudah pernah melakukan pembelian produk secara online. Di antara 98 persen konsumen yang sudah pernah melakukan pembelian online, 42 persen menyatakan sudah pernah mengkases situs Tokopedia.com, namun belum melakukan pembelian melalui situs tersebut, padahal situs Tokopedia.com sudah muncul cukup lama dibandingkan situs-situs lainnya seperti Shopee, Lazada, Blibli dan Bukalapak. Tokopedia.com 
menyediakan berbagai jenis produk mulai elektronik, kebutuhan rumah tangga, makanan dan minuman sampai produk-produk fashion.

Untuk melancarkan kegiatan pemasarannya dan membangun pengetahuan produk yang baik, Tokopedia bekerjasama dengan beberapa instansi pemerintah seperti PLN, BPJS, PT. KAI, membuat promosi berupa voucher online yang dapat digunakan pada situs Tokopedia.com dan branding di media sosial. Tokopedia juga bekerjasama dengan lembaga perbankan dan agen-agen pengiriman besar di Indonesia sehingga konsumen mudah untuk melakukan pembayaran dan memudahkan untuk pengiriman barang hingga pegecekan status barang (Lupi \& Nurdin, 2016). Tetapi pengguna Tokopedia.com di Kota Denpasar relatif kecil jika dibandingkan dengan pengguna e-commerce lainnya. Hal ini disebabkan oleh kurangnya promosi produk yang ditawarkan pada situs Tokopedia.com, harga yang ditawarkan lebih mahal di situs Tokopedia.com, dan ongkos kirim yang dibebankan kepada konsumen. Hal ini menunjukan pengetahuan produk yang ditawarkan di situs Tokopedia.com kurang maksimal. Studi-studi terdahulu yang membahas pembelian online melalui e-commerce menunjukkan bahwa pengetahuan produk berpengaruh positif terhadap sikap konsumen untuk belanja online (Kusumaningtyas \& Mujiasih, 2016; Kusuma \& Untarini, 2014; Faidah \& Anam, 2018)

Kajian terhadap literatur dan hasil-hasil penelitian menunjukkan bahwa keputusan konsumen untuk mengakses dan melakukan pembelian online, salah satunya ditentukan oleh kualitas situs e-commerce. Berdasarkan hasil survei pendahuluan, pengguna situs e-commerce di Kota Denpasar sudah pernah mengunjungi situs Tokopedia.com, tetapi belum pernah melakukan pembelian di situs ini. Hal ini menunjukan bahwa kualitas situs yang meliputi informasi yang disediakan, tampilan pengguna pada situs Tokopedia.com kurang menarik pengguna situs e-commerce di Kota Denpasar. Kualitas e-commerce ditentukan oleh nilai tambah yang diberikan pada produk atau jasa dengan cara mengintegrasikan beberapa komponen dari sumber-sumber yang berbeda, interaksi pengguna dan kualitas layanan pada situs e-commerce itu sendiri. Informasi, interaksi pengguna dan kualitas layanan saat ini merupakan faktor-faktor yang mempengaruhi keefektifan dari sebuah situs secara signifikan (Aryadita et al., 2017). Studi-studi terdahulu menunjukkan bahwa terdapat pengaruh antara kualitas situs dan sikap untuk berbelanja online (Erdini \& Susilo, 2015;Kirana \& Junaedi, 2017; Manuel et al., 2017)

Sesuai dengan teori sikap yang banyak diacu dalam penelitian sebelumnya, sikap konsumen untuk membeli secara online memiliki peran penting dalam menentukan niat konsumen untuk membeli secara online dan selanjutnya niat tersebut akan mendorong konsumen untuk melakukan pembelian produk tertentu. Sikap merupakan ungkapan perasaan konsumen tentang suatu objek apakah disukai atau tidak, serta gambaran kepercayaan konsumen terhadap berbagai atribut dan manfaat dari objek tersebut. Studi-studi terdahulu menunjukkan bahwa sikap konsumen berpengaruh positif terhadap niat untuk membeli secara online (Eriyani \& Wiyono, 2012; Trisdayana et al., 2018)

Berdasar kondisi itu, perlu dilakukan penelitian untuk memperoleh informasi tentang tingginya persentase konsumen yang belum atau tidak menggunakan situs 
Tokopedia.com dalam melakukan pembelian online, sehingga hasilnya bisa digunakan oleh pihak e-commerce Tokopedia.com dalam merancang strategi pemasaran bagi produk-produknya. Alasan ini dapat dihubungkan dengan cukup tingginya hasil pra-survei yang menunjukkan persentase konsumen yang belum pernah pembelian online melalui e-commerce Tokopedia.com, maka penelitian ini dilakukan untuk menganalisis niat beli konsumen terhadap Tokopedia.com.

Penelitian ini memiliki tujuan untuk: (1) Menjelaskan pengaruh kualitas situs terhadap sikap belanja online di situs Tokopedia.com; (2) Menjelaskan pengaruh pengetahuan produk terhadap sikap belanja online di situs Tokopedia.com; dan (3) Menjelaskan pengaruh sikap belanja online terhadap niat beli online di situs Tokopedia.com.

Hasil penelitian ini diharapkan memberi sumbangan kajian empiris tentang hubungan variabel kualitas situs, sikap belanja online, dan niat beli yang diimplementasikan dalam konteks pembelian online melalui sebuah situs $e$ commerce. Secara praktis, hasil penelitian ini dapat dijadikan informasi, masukan dan bahan evaluasi bagi pengusaha di bidang UMKM yang berjualan secara online dalam upaya menentukan strategi pemasaran yang lebih baik untuk kemajuan usaha dalam jangka panjang.

Kualitas situs adalah nilai suatu situs yang membuat sebuah situs mudah digunakan oleh pengguna, terdapat informasi yang reliabel, tampilan situs yang menarik dan memenuhi ekspektasi pengguna situs (Anusha, 2014). Situs $e$ commerce dapat menyediakan pengguna dengan berbagai macam pilihan. Tetapi yang lebih penting, website dapat memberikan informasi lengkap kepada pengguna hingga kebiasaan pembelian mereka. Ini akan mempersingkat waktu yang digunakan untuk mencari produk yang mereka inginkan (Ye \& Ma, 2018). Situs yang berkualitas akan mampu mempengaruhi minat beli konsumen kualitas situs memainkan peran penting dalam membedakan merek dari merek lain dalam $e$ tailing, menjadikannya faktor penting kesuksesan bisnis situs web belanja (Shin et al., 2014)

Pengetahuan konsumen terhadap produk didefinisikan sebagai pengetahuan mengenai berbagai informasi yang dimiliki konsumen tentang karakteristik produk, seperti kelas produk, merek, dan model/fitur. Pengetahuan produk sebagai kumpulan berbagai macam informasi mengenai produk. Pengetahuan ini meliputi kategori produk, merek, terminologi produk, atribut atau fitur produk, harga produk, dan kepercayaan mengenai produk. Menurut Kusuma \& Untarini (2014) Seorang konsumen perlu mengetahui tentang produk terlebih dahulu sebelum sebelum ia membeli dan menyukai produk tersebut. Pengetahuan yang baik seringkali mendorong seseorang untuk menyukai produk tersebut. Konsumen cenderung memiliki pengetahuan produk yang kurang jika konsumen hanya mendapat informasi secara tidak langsung dari iklan di televisi dan internet (Kusumaningtyas \& Mujiasih, 2016)

Prasad \& Aryasri (2009) mengemukakan bahwa sikap merupakan suatu bentuk perasaan yang bersifat favourable atau unfavourable. Dengan demikian, sikap pada dasarnya menunjukkan kondisi mental atau pun rasionalitas tertentu yang mencerminkan suatu pandangan pribadi mengenai suatu objek ataupun konsep. Pandangan tersebut dapat berupa pandangan yang positif (bermanfaat) dan 
pandangan negatif (destruktif). Menurut Sugiarto (2012), sikap terhadap belanja online didefinisikan sebagai perasaan positif atau negatif konsumen yang berkaitan dengan dicapainya perilaku pembelian diinternet. Untuk menyelidiki sikap konsumen, kita perlu mengetahui apa karakteristik konsumen biasanya dalam pembelian online dan apa sikap mereka dalam pembelian online. Studi pemasaran menjelaskan analisis sikap merupakan bagian dari upaya mengenal konsumen dan perilaku konsumen dengan baik.

Perilaku membeli ditentukan oleh niat pembelian. Niat beli adalah rencana kognitif atau keinginan konsumen untuk membeli suatu barang atau merek tertentu. Niat membeli dapat diukur dengan menanyakan tentang kemungkinan membeli produk yang diiklankan.

Niat beli adalah tahap kecenderungan responden untuk bertindak sebelum benar-benar melakukan pembelian (Martinez, 2012). Menurut Meskaran et al. (2013) Terdapat perbedaan antara pembelian aktual dan kecenderungan pembelian. Bila pembelian aktual yaitu pembelian yang benar-benar dilakukan oleh konsumen, kecenderungan pembelian merupakan sebuah niat yang timbul pada konsumen untuk melakukan pembelian pada waktu yang akan datang. Menurut Thamizhvanan \& Xavier (2013) niat beli online adalah bagian dari keinginan pada diri konsumen untuk melakukan pembelian secara online, terdapat indikator niat beli yang digunakan oleh pelanggan dalam hal ini mengenali manfaat produk yang akan dibeli, gencar dalam pencarian informasi mengenai kualitas produk, keinginan untuk segera membeli produk dan memiliki kecenderungan terhadap produk tertentu.

Berdasarkan penelusuran pada kajian pustaka dan hasil-hasil penelitian empiris sebelumnya, maka kerangka konseptual adalah sebagai berikut.

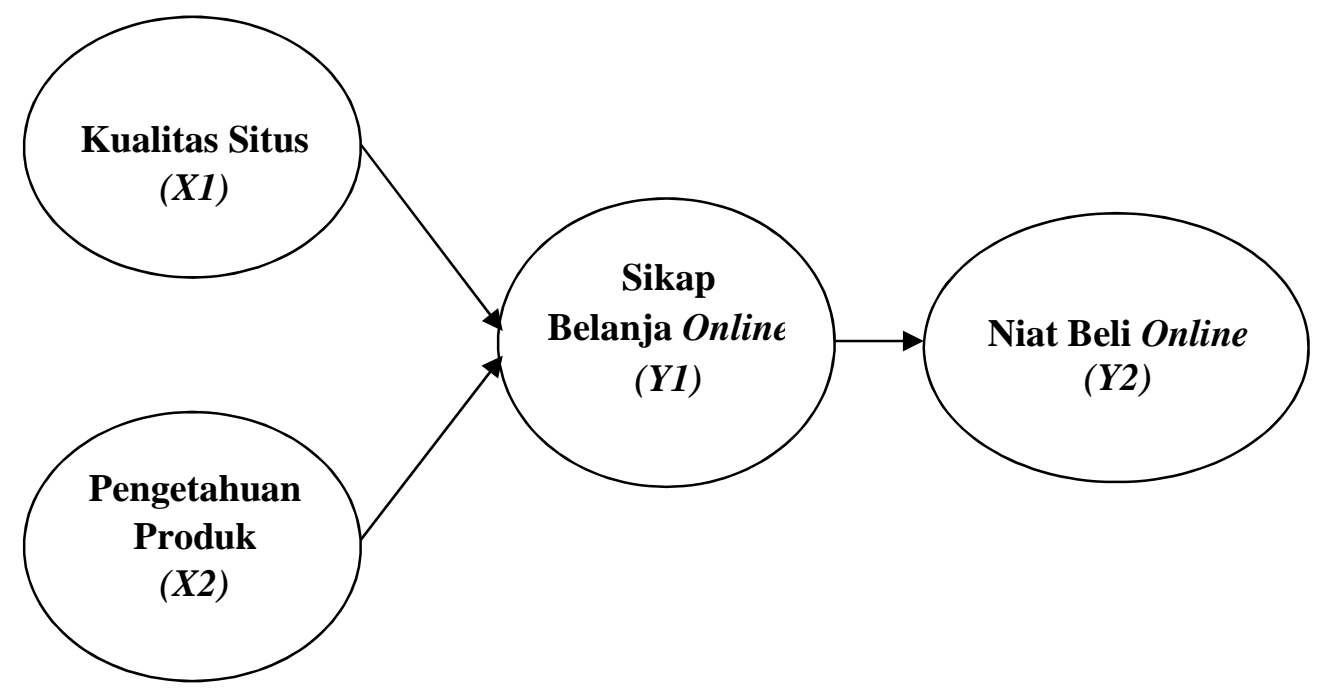

Gambar 1. Kerangka Konseptual

Sebuah penelitian yang dilaksanakan oleh Manuel et al. (2017) yang dilakukan untuk mengidentifikasi faktor yang mempengaruhi sikap konsumen menemukan hasil bahwa kualitas situs berpeFngaruh signifikan terhadap sikap belanja online. Penelitian yang dilakukan Kirana \& Junaedi (2017), Erdini \& Susilo 
(2015) juga menemukan bahwa terdapat pengaruh kualitas situs yang signifikan terhadap sikap belanja.

$\mathrm{H}_{1}$ : kualitas situs berpengaruh positif dan signifikan terhadap sikap belanja online.

Dalam penelitian Kusuma \& Untarini (2014) di WTC, Surabaya untuk mengidentifikasi faktor yang mempengaruhi sikap konsumen menemukan bahwa pengetahuan produk mempengaruhi sikap secara signifikan. Penelitian Kusumaningtyas \& Mujiasih (2016) dan Faidah \& Anam (2018) juga menemukan bahwa terdapat pengaruh pengetahuan produk yang signifikan terhadap sikap belanja.

$\mathrm{H}_{2}$ : Pengetahuan produk berpengaruh positif dan signifikan terhadap sikap belanja online.

Dalam penelitian Eriyani \& Wiyono (2012) di Universitas Sebelas Maret, Surakarta untuk mengidentifikasi faktor yang mempengaruhi niat beli konsumen terhadap produk kosmetik organik menemukan bahwa sikap mempengaruhi niat beli online secara signifikan. Pada penelitian yang dilakukan Trisdayana et al. (2018) menemukan bahwa terdapat pengaruh yang signifikan pada sikap terhadap niat beli online.

$\mathrm{H}_{3}$ : Sikap belanja online berpengaruh positif dan signifikan terhadap niat beli online.

\section{METODE PENELITIAN}

Penelitian ini termasuk jenis penelitian asosiatif yang bersifat kausal. Dinyatakan asosiatif karena penelitian menjelaskan mengenai pengaruh antar variabel dan dinyatakan bersifat kausal karena dalam model penelitian yang disajikan, satu variabel menentukan variabel lainnya. Lokasi penelitian ini adalah Kota Denpasar. Dasar dari pemilihan lokasi di Kota Denpasar karena berdasarkan data dari Badan Pusat Statistik (BPS), pengguna internet di Kota Denpasar berjumlah 291.000 jiwa. Data yang disajikan oleh Sloka Insitute (2015) menunjukkan bahwa Kota Denpasar merupakan kota dengan jumlah pengguna internet tertinggi di Provinsi Bali.

Obyek penelitian adalah perilaku konsumen yang sudah atau sering melakukan pembelian online melalui situs-situs e-commerce, khususnya yang meliputi pengetahuan konsumen tentang produk-produk yang dijual melalui situs Tokopedia.com, penilaian konsumen tentang kualitas situs Tokopedia.com, sikap konsumen untuk pembelian online, dan niat belinya untuk pembelian secara online di situs Tokopedia.com. Variabel independen yaitu variabel kualitas situs Tokopedia.com $\left(\mathrm{X}_{1}\right)$ dan pengetahuan produk $\left(\mathrm{X}_{2}\right)$. Variabel dependen adalah sikap belanja online $\left(\mathrm{Y}_{1}\right)$ dan niat beli online $\left(\mathrm{Y}_{2}\right)$

Data yang digunakan dikelompokkan berdasar sifatnya, yaitu data kuantitatf dan data kualitatif. Data kualitatif berupa data dari informasi yang tidak dapat dihitung atau tidak memiliki satuan hitung. Dalam penelitian ini, data kualitatif berupa pendapat responden terhadap setiap pernyataan yang diajukan kepada responden yang berkaitan dengan ukuran atau indikator-indikator tiap variabel penelitian. Data kuantitatif merupakan data yang dapat dihitung atau memiliki satuan hitung, antara lain jumlah pengguna internet yang berasal dari Asosiasi 
Penyelenggara Jasa Internet Indonesia (APJII) tahun 2017, serta umur dari responden.

Sumber data merupakan jenis data berdasarkan pada dari mana data tersebut diperoleh, antara lain 1) Sumber primer adalah responden penelitian. 2) Sumber sekunder yaitu berupa artikel pada website laman Sloka Institute yang bekerjasama dengan Asosiasi Penyelenggara Jasa Internet Indonesia (APJII) pada tahun 2015.

Instrumen yang digunakan untuk memperoleh data adalah kuesioner. Dalam penelitian ini, kuesioner terdiri atas tiga bagian, yaitu bagian pertama merupakan pertanyaan penyaring, bagian kedua menanyakan identitas responden, sedangkan bagian ketiga terdiri atas sejumlah pernyataan yang berasal dari indikator-indikator variabel penelitian. Pada bagian ketiga instrumen penelitian, tiap pernyataan diukur dengan menggunakan Skala Likert lima poin. Sebelum digunakan, instrumen penelitian ini perlu diuji validitas dan reliabilitasnya. Pengujian dilakukan dengan menyebar instrumen penelitian kepada 50 orang yang sudah pernah melakukan pembelian online dari beberapa situs e-commerce.

Populasi dalam penelitian ini adalah orang yang pernah berkunjung ke situs Tokopedia.com, tetapi belum pernah melakukan pembelian di situs ini. Situs Tokopedia.com ini tidak secara akurat mencatat jumlah pelanggannya sehingga tidak dapat diketahui dengan pasti. Karena itu, penentuan sampel menggunakan metode non-probability sampling yaitu teknik yang tidak memberi peluang atau kesempatan yang sama bagi setiap unsur atau anggota populasi untuk dipilih menjadi sampel. Salah satu metode non-probabilty sampling adalah purposive sampling yaitu teknik penentuan sampel dengan pertimbangan tertentu.

Adapun kriteria yang digunakan dalam menentukan sampel adalah Konsumen yang sudah sering melakukan pembelian secara online, sudah pernah mengunjungi situs Tokopedia.com namun belum pernah melakukan pembelian online di situs Tokopedia.com. Pertimbangan ini digunakan dengan alasan seseorang dapat melihat fitur yang diberikan oleh situs Tokopedia.com dan pendidikan terakhir minimal SMA/SMK sederajat. Pertimbangan ini digunakan dengan alasan seseorang dengan jenjang pendidikan minimal SMA/SMK dapat memahami isi dari kuesioner.

Ukuran sampel yang digunakan berada pada rentang antar 75 sampai 150 . Untuk memperoleh ukuran sampel tersebut, disebarkan 200 eksemplar kuesioner, namun yang kembali dan lengkap untuk diolah sebanyak 113 eksemplar. Dengan demikian ukuran sampel dalam penelitian ini adalah 113 orang. Data yang diperoleh dari responden anggota sampel dikumpulkan melalui metode survei, yaitu menyebarkan instrumen penelitian berupa kueisoner. Peneliti melakukan pendekatan kepada calon responden yang pernah melakukan pembelian secara online, sudah pernah mengunjungi situs Tokopedia.com namun belum pernah melakukan pembelian online di situs Tokopedia.com agar bersedia menjadi responden, dan meminta kesediaan untuk mengisi kuesioner secara online dan dikirim melalui email. Peneliti dibantu oleh 5 orang teman menyebarkan kueisoner secara digital kepada orang yang pernah melakukan pembelian secara online. Untuk memperoleh responden antara 75 sampai 150 orang peneliti menyebar kueisoner kepada 200 pembeli online dari beberapa situs e-commerce. 


\section{HASIL DAN PEMBAHASAN}

Awal berdirinya situs ini dicetuskan oleh William Tanuwijaya dan Leontinus Alpha Edison yang resmi diluncurkan ke publik pada 17 Agustus 2009 di bawah naungan PT Tokopedia yang didirikan pada 6 Februari 2009. Sejak resmi diluncurkan, PT Tokopedia berhasil menjadi salah satu perusahaan internet Indonesia dengan pertumbuhan yang sangat pesat. Penggunaan brand ambassador yaitu penyanyi terkenal Isyana Saraswati serta selebriti muda yang sangat bertalenta Chelsea Islan menjadikan Tokopedia dengan cepat merambah pasar yang luas hanya dalam rentang waktu yang singkat. Dengan berbagai kemudahan yang ditawarkan oleh Tokopedia, hanya dalam waktu singkat dapat menjaring banyak konsumen. Tokopedia.com memiliki visi untuk "Membangun Indonesia yang Lebih Baik Lewat Internet" sehingga program yang diusung untuk mendukung para pelaku Usaha Mikro Kecil dan Menengah (UMKM) dan perorangan untuk mengembangkan usaha mereka dengan memasarkan produk secara online.

E-commerce yang ada di Indonesia antara lain tokopedia.com, bukalapak.com, blibli.com, zalora, lazada, dan sebagainya. Salah satu jenis $e$ commerce yang cukup populer di Indonesia adalah tokopedia.com. Didirikan pada 17 Agustus 2009 dengan visi membangun Indonesia lebih baik melalui internet, tokopedia.com tumbuh sangat pesat dan menjadi e-commerce terbesar di Indonesia. Sejak berdiri, tokopedia.com pernah meraih penghargaan Bubu Awards pada tahun 2009 dimana tokopedia.com dinobatkan sebagai perusahaan $e$-commerce terbaik. Selain itu tokopedia.com telah berhasil mendapatkan investasi dari PT Indonusa Dwitama (2009), East Ventures (2010), CyberAgent Ventures (2011), BEENOS (2012), SB Pan Asia Fund (2013), dan SoftBank Internet and Media, Inc. ("SIMI") dan Sequoia Capital (2014).

Tokopedia.com merupakan online e-commerce yang memungkinkan setiap individu dan pemilik bisnis di Indonesia membuka dan mengurus toko online mereka secara mudah dan bebas biaya, sekaligus memberikan pengalaman jual beli online secara aman dan nyaman. Dengan slogan lebih lengkap, lebih aman, dan lebih murah tokopedia.com memungkinkan penggunanya untuk dapat memilih beragam produk yang ada di tokopedia.com secara online tanpa perlu khawatir terhadap penipuan. Selain itu sebagai mall online yang merupakan tempat berkumpulnya toko-toko online terpercaya di seluruh Indonesia, pengguna atau yang sering disebut toppers dapat membandingkan harga dari berbagai toko yang ada di tokopedia.com, sehingga memungkinkan toppers untuk mendapatkan produk yang diinginkan dengan harga yang lebih murah.

Tabel 1.

Hasil Uji Validitas Instrumen Penelitian

\begin{tabular}{lllll}
\hline Variabel & Indikator & r itung & r tabel & Keterangan \\
\hline Kualitas Situs $\left(\mathrm{X}_{1}\right)$ & $\mathrm{X} 1_{.1}$ & 0,910 & 0,3 & Valid \\
& $\mathrm{X} 1_{.2}$ & 0,860 & 0,3 & Valid \\
& $\mathrm{X} 1_{.3}$ & 0,874 & 0,3 & Valid \\
& $\mathrm{X} 1_{.4}$ & 0,906 & 0,3 & Valid \\
& $\mathrm{X} 1_{.5}$ & 0,910 & 0,3 & Valid \\
& $\mathrm{X} 1.6$ & 0,853 & 0,3 & Valid \\
Pengetahuan Produk $\left(\mathrm{X}_{2}\right)$ & $\mathrm{X} 2.1$ & 0,970 & 0,3 & Valid \\
& $\mathrm{X} 2.2$ & 0,891 & 0,3 & Valid \\
& $\mathrm{X} 2.3$ & 0,806 & 0,3 & Valid \\
\hline
\end{tabular}

Bersambung... 
Lanjutan Tabel 1.

\begin{tabular}{lllll}
\hline Variabel & Indikator & r itung & r tabel & Keterangan \\
\hline Sikap Belanja Online $(\mathrm{Y} 1)$ & $\mathrm{Y} 1.1$ & 0,929 & 0,3 & Valid \\
& $\mathrm{Y} 1.2$ & 0,901 & 0,3 & Valid \\
& $\mathrm{Y} 1.3$ & 0,932 & 0,3 & Valid \\
Niat Membeli Online $\left(\mathrm{Y}_{2}\right)$ & $\mathrm{Y} 2.1$ & 0,886 & 0,3 & Valid \\
& $\mathrm{Y} 2.2$ & 0,928 & 0,3 & Valid \\
& $\mathrm{Y} 2.3$ & 0,890 & 0,3 & Valid \\
\hline
\end{tabular}

Sumber: Data diolah, 2019

Hasil uji validitas pada Tabel 1. menunjukkan bahwa seluruh instrumen penelitian yang digunakan untuk mengukur variabel kualitas situs, pengetahuan produk, sikap belanja online dan niat membeli online memiliki nilai koefisien korelasi dengan skor total seluruh item pernyataan lebih besar dari $r$ tabel yakni 0,3 . Hal ini menunjukkan bahwa butir-butir pernyataan dalam instrument penelitian tersebut valid dan layak digunakan sebagai instrument penelitian.

Uji reliabilitas mampu menunjukkan sejauh mana instrumen dapat dipercaya dan diandalkan. Untuk menguji realibilitas data digunakan teknik analisis formula Alpha Cronbach dengan bantuan software SPSS for Windows ver.24.. Nilai suatu instrumen dikatakan reliabel apabila nilai Alpha Cronbach $\searrow 0,60$. Hasil uji reliabilitas yang disajikan dalam Tabel 2 menunjukkan bahwa seluruh instrumen penelitian memiliki koefisien Cronbach's Alpha lebih dari 0,60. Jadi dapat dinyatakan bahwa seluruh variabel telah memenuhi syarat reliabilitas atau kehandalan sehingga dapat digunakan untuk melakukan penelitian.

Tabel 2.

Hasil Uji Reliabilitas Instrumen Penelitian

\begin{tabular}{clll}
\hline No. & Variabel & Cronbach'sAlpha & Keterangan \\
\hline $\mathbf{1}$ & Kualitas Situs $\left(\mathrm{X}_{1}\right)$ & 0,944 & Reliabel \\
$\mathbf{2}$ & Pengetahuan Produk $\left(\mathrm{X}_{2}\right)$ & 0,868 & Reliabel \\
$\mathbf{3}$ & Sikap Belanja Online $(\mathrm{Y} 1)$ & 0,904 & Reliabel \\
$\mathbf{4}$ & Niat Membeli Online $(\mathrm{Y} 2)$ & 0,876 & Reliabel \\
\hline
\end{tabular}

Sumber: Data diolah, 2019

Tabel 3.

Profil Responden Menurut Jenis Kelamin dan Usia

\begin{tabular}{|c|c|c|c|c|}
\hline No & Variabel & Klasifikasi & Jumlah (orang) & Persentase \\
\hline \multirow[t]{2}{*}{1.} & Jenis Kelamin & Laki - Laki & 58 & 51,3 \\
\hline & & Perempuan & 55 & 48,7 \\
\hline \multicolumn{2}{|c|}{ Jumlah } & & 113 & 100 \\
\hline \multirow[t]{6}{*}{2.} & Usia & $18-21$ Tahun & 69 & 61,1 \\
\hline & & $22-25$ Tahun & 38 & 33,6 \\
\hline & & 26 - 29 Tahun & 2 & 1,8 \\
\hline & & $30-33$ Tahun & 1 & 0,9 \\
\hline & & $34-37$ Tahun & 0 & 0,0 \\
\hline & & > 37 Tahun & 3 & 2,6 \\
\hline \multicolumn{2}{|c|}{ Jumlah } & & 113 & 100 \\
\hline \multirow[t]{2}{*}{3.} & Pendidikan & Perguruan Tinggi & 56 & 49,6 \\
\hline & & SMA & 57 & 50,4 \\
\hline \multicolumn{2}{|c|}{ Jumlah } & & 113 & 100 \\
\hline
\end{tabular}

Sumber: Data diolah, 2019 
Pada Tabel 3 jika dilihat dari jenis kelamin, sebagian besar responden berjenis kelamin laki - laki yakni 51,3 persen. Jika dilihat dari usia, 18 - 21 Tahun adalah usia yang paling mendominasi diantara yang lainnya yaitu $61,1 \%$. Dilihat dari pendidikan terakhir, responden didominasi tamatan SMA yakni 50,4\%.

Tabel 4.

Deskripsi Jawaban Responden Terhadap Kualitas Situs

\begin{tabular}{|c|c|c|c|c|c|c|c|c|}
\hline \multirow[t]{2}{*}{ No } & \multirow[t]{2}{*}{ Pernyataan } & \multicolumn{5}{|c|}{ Frekuensi Jawaban Responden } & \multirow[t]{2}{*}{ Rata-Rata } & \multirow[t]{2}{*}{ Keterangan } \\
\hline & & STS & TS & $\mathbf{N}$ & $\mathbf{S}$ & SS & & \\
\hline 1 & $\begin{array}{l}\text { Saya merasa tampilan } \\
\text { situs } \quad \text { Tokopedia.com } \\
\text { menarik ketika diakses. } \\
\text { Saya merasa situs }\end{array}$ & 1 & 4 & 28 & 61 & 19 & 3,82 & Baik \\
\hline 2 & $\begin{array}{l}\text { Tokopedia.com terbilang } \\
\text { cepat ketika diakses. }\end{array}$ & 0 & 6 & 35 & 51 & 21 & 3,77 & Baik \\
\hline 3 & $\begin{array}{l}\text { Saya merasa informasi } \\
\text { yang diberikan di situs } \\
\text { Tokopedia.com terpapar } \\
\text { dengan jelas }\end{array}$ & 0 & 6 & 33 & 54 & 20 & 3,78 & Baik \\
\hline 4 & $\begin{array}{l}\text { Saya merasa informasi } \\
\text { yang diberikan di situs } \\
\text { Tokopedia.com akurat }\end{array}$ & 0 & 5 & 46 & 45 & 17 & 3,65 & Baik \\
\hline 5 & $\begin{array}{l}\text { Saya merasa informasi di } \\
\text { situs Tokopedia.com } \\
\text { sering diperbarui }\end{array}$ & 0 & 6 & 45 & 36 & 26 & 3,73 & Baik \\
\hline 6 & $\begin{array}{l}\text { Saya merasa mudah dalam } \\
\text { mengoperasikan situs } \\
\text { Tokopedia.com }\end{array}$ & 0 & 5 & 25 & 45 & 38 & 4,03 & Baik \\
\hline \multicolumn{7}{|c|}{ Rata-rata keseluruhan variabel kualitas situs } & 3,80 & \\
\hline
\end{tabular}

Sumber: Data diolah, 2019

Variabel kualitas situs dalam penelitian ini diukur dengan menggunakan 6 pernyataan. Secara rinci hasil penelitian mengenai jawaban responden terhadap variabel kualitas situs dapat dilihat pada Tabel 4 yang menunjukkan kualitas situs secara keseluruhan adalah baik, hal ini dapat dilihat dari keseluruhan rata-rata nilai Kualitas Situs yaitu 3,80. Nilai rata-rata tertinggi pada pernyataan "Saya merasa mudah dalam mengoperasikan situs Tokopedia.com". Hal ini menunjukkan responden merasa mudah dalam mengoperasikan situs Tokopedia.com. Nilai ratarata terendah terdapat pada pernyataan "Saya merasa informasi yang diberikan di situs Tokopedia.com akurat". Meskipun skornya lebih lebih rendah, namun masih berada dalam kategori baik. Itu berarti informasi yang diberikan oleh Tokopedia sudah dipahami oleh responden.

Variabel pengetahuan produk dalam penelitian ini merupakan variabel bebas yang diukur dengan menggunakan 3 pernyataan yang berhubungan dengan pengetahuan produk dari responden. Secara rinci hasil penelitian mengenai jawaban responden terhadap variabel pengetahuan produk dapat dilihat pada Tabel 5 berikut.

Tabel 5. menunjukkan pengetahuan produk secara keseluruhan adalah baik, hal ini dapat dilihat dari keseluruhan rata-rata nilai pengetahuan produk yaitu 3,62. Nilai rata-rata tertinggi pada pernyataan "Saya sudah pernah menggunakan beberapa produk sejenis yang ditawarkan melalui situs Tokopedia.com". Hal ini menunjukan dominan responden sudah pernah menggunakan beberapa produk 
sejenis yang ditawarkan melalui situs Tokopedia.com. Nilai rata-rata terendah terdapat pada pernyataan "Saya memiliki pengetahuan yang baik tentang produkproduk yang ditawarkan melalui situs Tokopedia.com". Hal ini menunjukan bahwa responden kurang memaksimalkan pengetahuan yang baik tentang produk produk yang ditawarkan melalui situs Tokopedia.com sehingga dapat memudahkan dalam berbelanja.

Tabel 5.

Deskripsi Jawaban Responden Terhadap Pengetahuan Produk

\begin{tabular}{|c|c|c|c|c|c|c|c|c|}
\hline \multirow[t]{2}{*}{ No } & \multirow[t]{2}{*}{ Pernyataan } & \multicolumn{5}{|c|}{ Frekuensi Jawaban Responden } & \multicolumn{2}{|c|}{ RataRata Keterangan } \\
\hline & & STS & TS & $\mathbf{N}$ & $\mathbf{S}$ & SS & & \\
\hline 1 & $\begin{array}{l}\text { Saya memiliki pengetahuan } \\
\text { yang baik tentang produk- } \\
\text { produk yang ditawarkan } \\
\text { melalui } \\
\text { Tokopedia.com }\end{array}$ & 1 & 12 & 41 & 45 & 14 & 3,52 & Baik \\
\hline 2 & $\begin{array}{l}\text { Saya merasa sangat paham } \\
\text { dengan produk-produk } \\
\text { yang ditawarkan melalui } \\
\text { situs Tokopedia.com }\end{array}$ & 0 & 8 & 42 & 43 & 20 & 3,66 & Baik \\
\hline 3 & $\begin{array}{lr}\text { Saya sudah } & \text { pernah } \\
\text { menggunakan beberapa } \\
\text { produk sejenis yang } \\
\text { ditawarkan melalui } & \text { situs } \\
\text { Tokopedia.com } & \end{array}$ & 2 & 11 & 32 & 45 & 23 & 3,67 & Baik \\
\hline \multicolumn{7}{|c|}{ Rata-rata keseluruhan variabel Pengetahuan Produk } & 3.62 & \\
\hline
\end{tabular}

Tabel 6.

Deskripsi Jawaban Responden Terhadap Variabel Sikap Belanja Online

No Pernyataan Frekuensi Jawaban Responden Rata-Rata Keterangan

\begin{tabular}{|c|c|c|c|c|c|c|c|c|}
\hline & \multirow{2}{*}{ STS } & & & & & & \\
\hline & & & TS & $\mathbf{N}$ & $\mathbf{S}$ & SS & & \\
\hline 1 & $\begin{array}{l}\text { Saya } \\
\text { akan kerasa yakin } \\
\text { barang keguaan } \\
\text { barang yang akan } \\
\text { saya beli di situs } \\
\text { Tokopedia.com }\end{array}$ & 1 & 9 & 39 & 45 & 19 & 3,64 & Baik \\
\hline 2 & $\begin{array}{l}\text { Saya merasa produk- } \\
\text { produk yang } \\
\text { ditawarkan } \\
\text { Tokopedia.com } \\
\text { tergolong baik. }\end{array}$ & 1 & 4 & 31 & 57 & 20 & 3,81 & Baik \\
\hline 3 & $\begin{array}{l}\text { Saya merasa tertarik } \\
\text { terhadap produk- } \\
\text { produk } \\
\text { ditawarkan di sang } \\
\text { Tokopedia.com } \\
\text {-rata keseluruhan var }\end{array}$ & iabel S & ap B & 36 & nline & 17 & 3,67 & Baik \\
\hline
\end{tabular}

Variabel sikap belanja online dalam penelitian ini merupakan variabel mediasi yang diukur dengan menggunakan 3 pernyataan yang berhubungan dengan 
sikap. Secara rinci hasil penelitian mengenai persepsi responden terhadap variabel sikap belanja online disajikan pada Tabel 6. yang menunjukkan secara keseluruhan rata-rata adalah baik, hal ini dapat dilihat dari keseluruhan rata-rata nilai pengetahuan produk yaitu 3,71. Nilai rata-rata tertinggi pada pernyataan "Saya merasa produk-produk yang ditawarkan Tokopedia.com tergolong baik.". Hal ini menunjukan dominan responden merasa produk yang ditawarkan melalui situs Tokopedia.com tergolong baik. Nilai rata-rata terendah terdapat pada pernyataan "Saya merasa yakin akan kegunaan barang yang akan saya beli di situs Tokopedia.com". Hal ini menunjukan bahwa responden kurang yakin akan kegunaan barang yang akan dibeli di situs Tokopedia.com.

Tabel 7.

Deskripsi Jawaban Responden Terhadap Variabel Niat Beli Online

\begin{tabular}{|c|c|c|c|c|c|c|c|c|}
\hline \multirow[t]{2}{*}{ No } & \multirow[t]{2}{*}{ Pernyataan } & \multicolumn{5}{|c|}{ Frekuensi Jawaban Responden } & \multirow[t]{2}{*}{ Rata-Rata } & \multirow[t]{2}{*}{ Keterangan } \\
\hline & & STS & TS & $\mathbf{N}$ & $\mathbf{S}$ & SS & & \\
\hline 1 & $\begin{array}{l}\text { Saya akan memilih } \\
\text { situs Tokopedia.com } \\
\text { sebagai media belanja } \\
\text { online }\end{array}$ & 2 & 5 & 40 & 45 & 21 & 3,69 & Baik \\
\hline 2 & $\begin{array}{l}\text { Saya ingin membeli } \\
\text { produk-produk yang } \\
\text { ditawarkan di } \\
\text { Tokopedia.com }\end{array}$ & 1 & 4 & 41 & 43 & 24 & 3,75 & Baik \\
\hline 3 & \begin{tabular}{lr} 
Saya akan membeli \\
produk yang & saya \\
inginkan di & situs \\
\multicolumn{3}{l}{ Tokopedia.com } &
\end{tabular} & 1 & 7 & 36 & 45 & 24 & 3,74 & Baik \\
\hline \multicolumn{6}{|c|}{ Rata-rata keseluruhan variabel Niat Membeli Online } & & 3,73 & \\
\hline
\end{tabular}

Niat membeli online dalam penelitian ini merupakan variabel terikat yang diukur dengan menggunakan 3 pernyataan yang berhubungan dengan niat membeli online. Secara rinci hasil penelitian mengenai persepsi responden terhadap variabel niat membeli online disajikan pada Tabel 7. yang menunjukkan secara keseluruhan rata-rata adalah baik, hal ini dapat dilihat dari keseluruhan rata-rata nilai pengetahuan produk yaitu 3,73. Nilai rata-rata tertinggi terdapat pada pernyataan "Saya ingin membeli produk-produk yang ditawarkan di situs Tokopedia.com". Hal ini menunjukan bahwa dominan responden ingin membeli produk-produk yang ditawarkan di situs Tokopedia.com. Nilai rata-rata terendah terdapat pada pernyataan "Saya akan memilih situs Tokopedia.com sebagai media belanja online". Hal ini beberapa responden belum yakin akan memilih situs Tokopedia.com sebagai media belanja online.

Berdasarkan data yang disajikan pada Tabel 8, maka persamaan regresi struktural (1) Dapat disusun sebagai berikut.

$\mathrm{Y}_{1}=\beta_{1} \mathrm{X}_{1}+\beta_{2} \mathrm{X}_{2}+\mathrm{e}_{1}$

$\mathrm{Y} 1=0,452 \mathrm{X}_{1}+0,439 \mathrm{X}_{2}+\mathrm{e}_{1}$ 
Tabel 8.

Hasil Analisis Model Regresi 1

\begin{tabular}{llllll}
\hline Variabel & \multicolumn{2}{l}{$\begin{array}{l}\text { Unstandardized } \\
\text { Coefficients }\end{array}$} & $\begin{array}{l}\text { Standardized } \\
\text { Coefficients }\end{array}$ & $\begin{array}{l}\mathbf{t} \\
\text { hitung }\end{array}$ & Sig. uji t \\
\hline & $\mathrm{B}$ & Std. Error & Beta & & \\
(Constant) & 0,191 & 0,273 & & 0,69 & 0,486 \\
& & & & 9 & \\
Kualitas Situs $\left(\mathrm{X}_{1}\right)$ & 0,508 & 0,079 & 0,452 & 6,40 & 0,000 \\
& & & & 2 & \\
Pengetahuan Produk & 0,439 & 0,070 & 0,439 & 6,22 & 0,000 \\
$\left(\mathrm{X}_{2}\right)$ & & & & 7 & \\
R Square & 0,612 & & & & \\
F Statistik & 86,691 & & & & \\
Signifikansi Uji F & 0,000 & & & &
\end{tabular}

Tabel 9.

Hasil Analisis Model Regresi 2

\begin{tabular}{llllll}
\hline Variabel & \multicolumn{2}{l}{$\begin{array}{l}\text { Unstandardized } \\
\text { Coefficients }\end{array}$} & $\begin{array}{l}\text { Standardized } \\
\text { Coefficients }\end{array}$ & $\begin{array}{l}\mathbf{t} \\
\text { hitung }\end{array}$ & $\begin{array}{l}\text { Sig. uji } \\
\mathbf{t}\end{array}$ \\
\hline & B & Std. Error & Beta & & \\
(Constant) & 0,820 & 0,249 & & 3,289 & 0,001 \\
Sikap ( $\left.\mathrm{Y}_{1}\right)$ & 0,785 & 0,066 & 0,748 & 11,891 & 0,000 \\
R Square & 0,560 & & & & \\
F Statistik & 141,404 & & & & \\
Signifikansi Uji & 0,000 & & & & \\
F & & & & & \\
\hline
\end{tabular}

Sumber: Data diolah, 2019

Berdasarkan data yang disajikan pada Tabel 9, maka persamaan regresi struktural (2) Dapat disusun sebagai berikut.

$\mathrm{Y}_{2}=\beta_{3} \mathrm{Y}_{1}+\mathrm{e}_{2}$

$\mathrm{Y}_{2}=0,748 \mathrm{Y}_{1}+\mathrm{e}_{2}$

Uji asumsi klasik dilakukan untuk memastikan hasil yang diperoleh memenuhi asumsi dasar di dalam analisis regresi. Uji normalitas dilakukan dengan menguji normalitas residual dengan menggunakan uji statistik KolmogorovSmirnov. Data dikatakan berdistribusi dengan normal apabila koefisien Asymp. Sig lebih besar dari $\alpha=0,05$.

Tabel 10.

Hasil Uji Normalitas Model 1

\begin{tabular}{ll}
\hline & Unstandardized Residual \\
\hline $\mathrm{N}$ & 113 \\
Kolmogorov-Smirnov & 1,122 \\
Asymp Sig (2-tailed) & 0,161 \\
\hline
\end{tabular}

Sumber: Data diolah, 2019 
Berdasarkan Tabel 10. dapat dilihat bahwa nilai Kolmogorov Sminarnov (KS) sebesar 1,122 dan nilai Asymp Sig (2-tailed) sebesar 0,161, hasil tersebut mengindikasikan bahwa model persamaan regresi tersebut berdistribusi normal karena nilai Asymp Sig (2-tailed) lebih besar dari nilai alpha 0,05.

Tabel 11.

Hasil Uji Normalitas Model 2

\begin{tabular}{ll}
\hline \multirow{2}{N}{} & Unstandardized Residual \\
\cline { 2 - 2 } Kolmogorov-Smirnov & $\mathbf{1 1 3}$ \\
Asymp Sig (2-tailed) & 0,931 \\
\hline
\end{tabular}

Sumber: Data diolah, 2019

Berdasarkan Tabel 11. dapat dilihat bahwa nilai Kolmogorov Sminarnov (KS) sebesar 0,931 dan nilai Asymp Sig (2-tailed) sebesar 0,352, hasil tersebut mengindikasikan bahwa model persamaan regresi tersebut berdistribusi normal karena nilai Asymp Sig(2-tailed) lebih besar dari nilai alpha 0,05.

Untuk dapat mendeteksi ada atau tidaknya multikolinearitas dapat dilihat dari nilai tolerance dan nilai variance inflation factor (VIF). Jika nilai tolerance lebih dari 10 persen atau VIF kurang dari 10 maka dikatakan tidak ada multikolinearitas.

Tabel 12.

Hasil Uji Multikoleniaritas

\begin{tabular}{llll}
\hline Persamaan Struktur & Variabel & Tolerance & VIF \\
\hline $\mathrm{Y} 1=\beta_{1} \mathrm{X}_{1}+\beta_{2} \mathrm{X}_{2}+\mathrm{e}_{1}$ & Kualitas Situs $\left(\mathrm{X}_{1}\right)$ & 0,708 & 1,412 \\
& Pengetahuan Produk $\left(\mathrm{X}_{2}\right)$ & 0,708 & 1,412 \\
$\mathrm{Y} 2=\beta_{3} \mathrm{Y} 1+\mathrm{e}_{2}$ & Sikap (Y1) & 1,000 & 1,000 \\
\hline
\end{tabular}

Sumber: Data diolah, 2019

Berdasarkan Tabel 12. dapat dilihat bahwa nilai tolerance dan VIF dari variabel kualitas situs, pengetahuan produk dan sikap belanja online menunjukkan nilai tolerance untuk setiap variabel lebih besar dari 0,1 dan nilai VIF lebih kecil dari 10 yang berarti model persamaan regresi bebas dari multikolinearitas.

Model regresi yang baik adalah model regresi yang mempunyai varian yang homogen. Jika suatu model regresi mengandung gejala heteroskedasitas maka akan memberikan hasil yang menyimpang. Regresi yang baik tidak mengandung gejala heteroskedastisitas jika semua variabel bebas tidak berpengaruh signifikan terhadap nilai yang absolute residual atau nilai signifikansinya diatas 0,05 akan memperlihatkan bahwa model yang dibuat tidak mengandung gejala heteroskedasistisitas.

Tabel 13.

Hasil Uji Heteroskedastisitas Model 1

\begin{tabular}{lll}
\hline No & Variabel & Signifikan \\
\hline 1 & Kualitas Situs & 0,116 \\
2 & Pengetahuan Produk & 0,158 \\
\hline Sumber: Data diolah, 2019
\end{tabular}


Pada Tabel 13. dapat dilihat bahwa nilai signifikansi dari variabel kualitas situs sebesar 0,116. Nilai signifikansi dari variabel pengetahuan produk sebesar 0,158 . Nilai tersebut lebih besar dari 0,05 yang berarti tidak terdapat pengaruh antara variabel bebas terhadap absolute residual. Dengan demikian, model yang dibuat tidak mengandung gejala heteroskedastisitas.

Tabel 14.

Hasil Uji Heteroskedastisitas Model 2

\begin{tabular}{lll}
\hline No & Variabel & Signifikan \\
\hline 1 & Sikap Belanja Online & 0,158 \\
\hline Sumber: Data diolah, 2019
\end{tabular}

Pada Tabel 14. dapat dilihat bahwa nilai signifikansi dari variabel sikap belanja online sebesar 0,158. Nilai tersebut lebih besar dari 0,05 yang berarti tidak terdapat pengaruh antara variabel bebas terhadap absolute residual. Dengan demikian, model yang dibuat tidak mengandung gejala heteroskedastisitas.

Uji ketepatan model masing - masing struktur menggunakan uji anova / uji F. Apabila signifikansi Uji F masing - masing struktur $<0,05$ maka model struktural dikatakan valid.

Tabel 15.

Hasil Analisis Ketepatan Model

\begin{tabular}{lll}
\hline No & Model & Signifikan $\mathbf{F}$ \\
\hline 1 & Model Struktural 1 & 0,000 \\
2 & Model Struktural 2 & 0,000 \\
\hline
\end{tabular}

Sumber: Data diolah, 2019

Berdasarkan Tabel 15. hasil uji ketepatan model (uji F) diperoleh nilai signifikansi F untuk model struktural 1 sebesar 0,000. Nilai Signifikansi 0,000 < 0,05 mengindikasikan bahwa model struktural 1 layak untuk digunakan atau valid dan nilai signifikansi F untuk model struktural 2 sebesar 0,000. Nilai Signifikansi $0,000<0,05$ mengindikasikan bahwa model struktural 2 layak untuk digunakan atau valid. Hasil ini mempunyai arti bahwa kedua model valid.

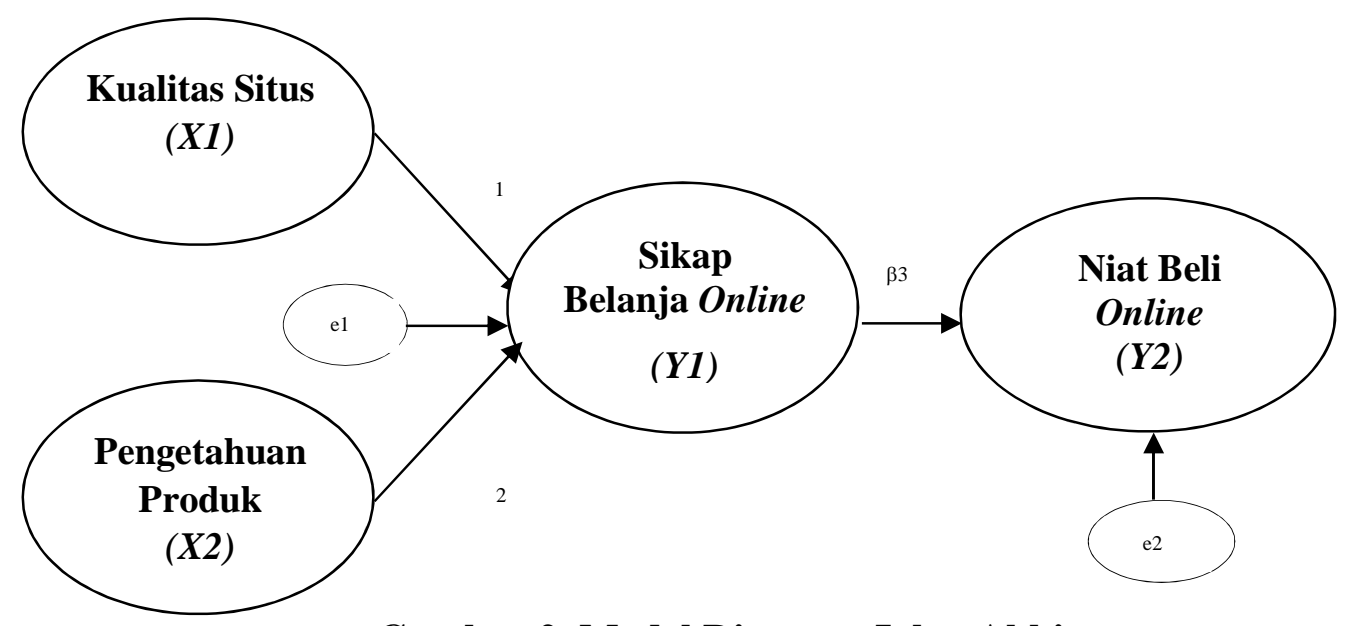

Gambar 2. Model Diagram Jalur Akhir 
Berdasarkan model 1 dan model 2, maka dapat disusun model diagram jalur akhir.

Sebelum menyusun model diagram jalur akhir, terlebih dahulu dihitung nilai standar eror sebagai berikut :

$\mathrm{Pe}_{\mathrm{i}}=\sqrt{1-\mathrm{R}_{\mathrm{i}}^{2}}$.

$\mathrm{Pe}_{1}=\sqrt{1-K_{1}{ }^{2}}=\sqrt{1-0,612}=0,623$

$\mathrm{Pe}_{2}=\sqrt{1-K_{2}{ }^{2}}=\sqrt{1-0,560}=0,663$

Berdasarkan perhitungan pengaruh error (Pei), didapatkan hasil pengaruh error $\left(\mathrm{Pe}_{1}\right)$ sebesar 0,623 dan pengaruh error $\left(\mathrm{Pe}_{2}\right)$ sebesar 0,663. Hasil koefisien determinasi total adalah sebagai berikut :

$$
\begin{aligned}
\mathrm{R}^{2} \mathrm{~m} & =1-\left(\mathrm{Pe}_{1}\right)^{2}\left(\mathrm{Pe}_{2}\right)^{2} \ldots \ldots \\
& =1-(0,623)^{2}(0,663)^{2} \\
& =1-(0,389)(0,440) \\
& =1-0,171=0,829
\end{aligned}
$$

Nilai determinasi total sebesar 0,830 mempunyai arti bahwa sebesar 82,9\% variasi niat membeli online dipengaruhi oleh variasi kualitas situs dan pengetahuan produk melalui sikap belanja online, sedangkan sisanya sebesar $17,1 \%$ djelaskan oleh faktor lain yang tidak dimasukkan ke dalam model.

Setelah melewati hasil uji asumsi klasik dan uji ketepatan model, maka persamaan regresi (1) dan persamaan regresi (2) yang ada di halaman 13 dan 14 dapat diintepretasikan sebagai berikut, nilai koefisien regresi masing-masing variabel bebas bernilai positif dengan nilai signifikansi uji t kurang dari 0,05. Hal ini menunjukkan bahwa semua variabel bebas memiliki pengaruh positif yang signifikan terhadap variabel terikat. Besarnya pengaruh variabel bebas terhadap variabel terikat yang ditunjukkan pada Tabel 8. nilai determinasi total (R Square) sebesar 0,612 yang mempunyai arti bahwa sebesar 61,2 persen variasi sikap belanja online dipengaruhi oleh variasi kualitas situs dan pengetahuan produk, sedangkan sisanya sebesar 38,8 persen dijelaskan oleh faktor lain yang tidak dimasukkan ke dalam model dan besarnya pengaruh variabel bebas terhadap variabel terikat yang ditunjukan pada Tabel 9, nilai determinasi total (R Square) sebesar 0,560 yang mempunyai arti bahwa 56,0 persen variabel niat beli online dipengaruhi oleh variabel sikap belanja online, sedangkan sisanya sebesar 44,0 persen dijelaskan oleh faktor lain yang tidak dimasukan kedalam model. Berdasarkan persamaan (1), pengaruh variabel kualitas situs $\left(\mathrm{X}_{1}\right)$ terhadap sikap belanja online $\left(\mathrm{Y}_{1}\right)$ adalah $\beta_{1}=$ 0,452 dan pengetahuan produk $\left(\mathrm{X}_{2}\right)$ terhadap sikap belanja online $\left(\mathrm{Y}_{1}\right)$ adalah $\beta_{2}=$ 0,439 , dan berdasarkan persamaan struktural (2), pengaruh variabel sikap belanja online $\left(\mathrm{Y}_{1}\right)$ terhadap niat beli online adalah $\beta_{3}=0,748$.

Pengaruh kualitas situs terhadap sikap belanja online diperoleh nilai signifikansi sebesar 0,000 dengan nilai koefisien beta 0,452 bernilai positif. Nilai Signifikansi 0,000 $\leq 0,05$ mengindikasikan bahwa $\mathrm{H}_{0}$ ditolak dan $\mathrm{H}_{1}$ diterima. Hasil ini mempunyai arti bahwa Kualitas Situs berpengaruh positif signifikan terhadap Sikap Belanja Online. Pengaruh pengetahuan produk terhadap sikap belanja online 
diperoleh nilai Signifikansi sebesar 0,000 dengan nilai koefisien beta 0,439 bernilai positif. Nilai Signifikansi $0,000 \leq 0,05$ mengindikasikan bahwa $\mathrm{H}_{0}$ ditolak dan $\mathrm{H}_{2}$ diterima. Hasil ini mempunyai arti bahwa Pengetahuan Produk berpengaruh positif signifikan terhadap Sikap Belanja Online. Pengaruh sikap belanja online terhadap niat membeli online diperoleh nilai Signifikansi sebesar 0,000 dengan nilai koefisien beta 0,748 bernilai positif. Nilai Signifikansi $0,000 \leq 0,05$ mengindikasikan bahwa $\mathrm{H}_{0}$ ditolak dan $\mathrm{H}_{3}$ diterima. Hasil ini mempunyai arti bahwa Sikap Belanja Online berpengaruh positif signifikan terhadap Niat Beli Online.

Berdasarkan hasil analisis diperoleh bahwa kualitas situs berpengaruh positif dan signigikan terhadap sikap belanja online di Tokopedia.com. Ini berarti, makin baik kualitas situs Tokopedia.com, maka makin baik sikap konsumen untuk belanja di situs tersebut. Hasil penelitian ini, sesuai dengan hasil penelitian yang dilakukan sebelumnya oleh Erdini \& Susilo (2015); Kirana \& Junaedi (2017); Hasanov \& Khalid (2015); Obiedat (2019); Wani et al. (2016); Tirtayani (2018); Bhatt \& Bhatt (2018); (Helversen, 2018) dan Manuel et al. (2017).

Berdasarkan hasil analisis diperoleh bahwa pengetahuan produk berpengaruh positif dan signifikan terhadap sikap belanja online di Tokopedia.com. Ini berarti, makin baik pengetahuan produk Tokopedia.com, maka makin baik sikap konsumen untuk belanja di Tokopedia.com. Hasil penelitian ini, sesuai dengan hasil penelitian yang dilakukan sebelumnya oleh Kusuma \& Untarini (2014); Kusumaningtyas \& Mujiasih (2016); Faidah \& Anam (2018); Imbayani et al. (2018); Kurniawan \& Indriani (2018); Haque (2015) dan Younus et al. (2015).

Berdasarkan hasil analisis diperoleh bahwa sikap belanja online berpengaruh positif dan signifikan terhadap niat beli online di Tokopedia.com. Ini berarti, makin baik sikap konsumen Tokopedia.com, maka makin baik niat beli di Tokopedia.com. Hasil penelitian ini, sesuai dengan hasil penelitian yang dilakukan sebelumnya oleh Eriyani \& Wiyono (2012); Bhatti (2018); Trisna \& Sefnedi (2018); Jung \& Seock (2016) dan Trisdayana et al. (2018).

Berdasarkan pemaparan di atas dapat ditinjau bahwa kualitas situs berpengaruh positif dan signifikan terhadap sikap belanja online. Hal tersebut mengindikasikan bahwa untuk meningkatkan sikap konsumen, maka manajemen Tokopedia.com sebaiknya meningkatkan kualitas situs, terutama dibagian keakuratan informasi yang nantinya akan mengarah pada meningkatkanya niat beli online, pihak Tokopedia sebaiknya mengotimalkan situsnya.

Selanjutnya, pengetahuan produk berpengaruh positif dan signifikan terhadap sikap belanja online. Hal tersebut mengindikasikan bahwa untuk meningkatkan sikap konsumen, maka manajemen Tokopedia.com sebaiknya meningoptimalkan pengetahuan produk, terutama dibagian pengetahuan yang baik tentang produk yang ditawarkan di situs Tokopedia.com yang nantinya akan mengarah pada meningkatkanya niat beli online, pihak Tokopedia sebaiknya melakukan promosi.

Sikap belanja online berpengaruh positif dan signifikan terhadap niat beli online. Hal tersebut mengindikasikan bahwa untuk meningkatkan niat beli online konsumen, maka manajemen Tokopedia.com sebaiknya meningoptimalkan sikap belanja online, terutama dibagian keyakina konsumen akan kegunaan barang yang 
akan dibeli di situs Tokopedia.com yang nantinya akan mengarah pada meningkatkanya niat beli online, pihak Tokopedia sebaiknya melakukan promosi harga dan layanan.

Berdasarkan hasil penelitian dan pembahasan di atas, didapat keterbatasan katerbatasan pada penelitian ini. Penelitian ini hanya dilakukan di Kota Denpasar dengan sampel 113 konsumen yang sering melakukan pembelian online. Dengan jumlah sampel yang terbatas ini, hasil penelitian ini tidak bisa digeneralisasi kepada seluruh populasi, karena populasi pengguna internet sangat banyak. Sampel penelitian didominasi oleh konsumen usia 17 - 25 tahun, padahal diluar kelompok usia tersebut, masih banyak konsumen yang melakukan pembelian online.

\section{SIMPULAN}

Berdasarkan hasil analisis penelitian dan hasil pembahasan pada bab sebelumnya maka simpulan dari penelitian ini adalah Kualitas situs berpengaruh positif terhadap sikap konsumen untuk belanja melalui situs Tokopedia.com. Hal ini menunjukan bahwa jika Kualitas Situs Tokopedia.com semakin meningkat maka akan meningkatkan pula sikap konsumen untuk belanja melalui situs Tokopedia.com. Pengetahuan produk berpengaruh positif terhadap sikap konsumen untuk belanja melalui situs Tokopedia.com. Hal ini menunjukan bahwa jika pengetahuan produk pada Tokopedia.com semakin meningkat maka akan meningkatkan pula sikap konsumen untuk belanja melalui situs Tokopedia.com. Sikap konsumen untuk belanja melalui situs Tokopedia.com berpengaruh positif terhadap niat beli online di situs Tokopedia.com. Hal ini menunjukan bahwa jika Sikap konsumen untuk belanja melalui situs Tokopedia.com semakin meningkat maka akan meningkatkan pula niat beli online di situs Tokopedia.com.

Adapun saran yang dapat diberikan yaitu bagi Management Tokopedia, hasil penelitian ini dapat digunakan sebagai dasar dalam meningkatkan niat beli online konsumen. Hal tersebut dapat dilakukan dengan cara mengoptimalkan tampilan situs sehingga lebih mudah digunakan oleh konsumen. Selain itu, langkah yang juga dapat dilakukan dengan cara menambah informasi yang dibutuhkan oleh konsumen agar lebih lengkap dan informatif. Bagi Peneliti berikutnya, hasil penelitian ini diharapkan dilakukan di kabupaten lain atau di provinsi lain dengan tingkat pengguna internet yang tinggi dan melakukan penelitian di kelompok usia selain usia 17-25 tahun. Selain itu, terdapat pembelian online yang sudah dilakukan oleh konsumen diluar Kota Denpasar. Pada penelitian selanjutnya, hal tersebut dapat ditanggulangi dengan cara menambah jumlah sampel dan melakukan penelitian di kabupaten lain.

\section{REFERENSI}

Anusha, R. (2014). A Study on Website Quality Models. International Journal of Scientific and Research Publications, 4(12), 1-20.

Aryadita, H., Widyastuti, D. A., \& Wardani, N. H. (2017). Analisis Kualitas Layanan Website e-Commerce Terhadap Kepuasan Pengguna Menggunakan Metode Webqual 4.0. Studia Informatika. Jurnal Sistem Informasi, 10(2), 2935 . 
Asosiasi Penyelenggara Jasa Internet Indonesia (APJII). (2017). Survey Pertumbuhan Pengguna Internet. Retrieved from www.tekno.kompas.com

Bhatt, S., \& Bhatt, A. (2018). Factors Influencing Online Shopping : An Empirical Study in Ahmedabad. The IUP Journal of Marketing Management, 1(6), 113.

Bhatti, A. (2018). Consumer Purchase Intention Effect on Online Shopping Behavior with the Moderating Role of Attitude. International Journal of Academic Management Science Research (IJAMSR), 2(7), 44-50. Retrieved from www.ijeais.org/ijamsr

Erdini, N., \& Susilo, W. H. (2015). Pengaruh Kualitas Dan Promosi Website Terhadap Sikap User Serta Implikasinya Kepada Keputusan Penggunaan Website Portal (Studi Kasus Website Portal Useetv.Com). Jurnal MIX, 5(3), $1-20$.

Eriyani, \& Wiyono. (2012). Pengaruh Sikap, Persepsi Kontrol Perilaku, Dan Norma Subjektif Pada Niat Beli Kosmetik Organik: Studi Pada Mahasiswa Universitas Sebelas Maret Surakarta. Fokus Manajerial, 11(2), 140-154.

Faidah, A. N., \& Anam, S. (2018). Pengaruh Pengetahuan Produk Terhadap Perilaku Memilih Lembaga Keuangan Syariah Dengan Sikap Terhadap Produk Sebagai Variabel Intervening (Studi Pada Masyarakat Muslim Desa Gambiran Kecamatan Mojoagung Kabupaten Jombang). Jurnal Administrasi Bisnis, 8(1), 2252.

Haque, A. (2015). Purchase Intention of Foreign Products: A Study on Bangladeshi Consumer Perspective. Saga Open, 5(2), 1-23.

Hasanov, J., \& Khalid, H. (2015). The Impact of Website Quality on Online Purchase Intention of Organic Food in Malaysia: A WebQual Model Approach. Elsevier, 72(1), 382-389. https://doi.org/10.1016/j.procs.2015.12.153

Helversen, B. (2018). Influence of consumer reviews on online purchasing decisions in older and younger adults. Decision Support Systems, 11(3), 113.

Imbayani, I. G. A., Wahyudi, A., \& Gama, S. (2018). The Influence of Electronic Word of Mouth ( E - Wom ), Brand Image, Product Knowledge on Purchase Intention. Jurnal Ekonomi Dan Bisnis Jagaditha, 5(1), 145-153.

Jung, N. Y., \& Seock, Y. K. (2016). The impact of corporate reputation on brand attitude and purchase intention. Fashion and Textiles, 3(1). https://doi.org/10.1186/s40691-016-0072-y 
Kirana, C. D., \& Junaedi, S. (2017). Pengaruh Kualitas Website, Ewom, Perceived Benefits, Dan Kepercayaan Terhadap Sikap Pada Belanja Online Di Lazada. Jurnal Atmajaya, 1(1), 1-20.

Kurniawan, H. A., \& Indriani, F. (2018). Pengaruh Productknowledge, Perceived Quality, Perceived Risk, Dan Perceived Value Terhadap Purchase Intentionpada Motor Kawasaki Ninja 250 Fi Di Kota Semarang. Diponegoro Journal Of Management, 7(4), 1-13.

Kusuma, I. D., \& Untarini, N. (2014). Pengaruh Pengetahuan Produk Terhadap Niat Beli Dengan Sikap Sebagai Variabel Intervening. Jurnal Ilmu Manajemen, 2(4), 1-20.

Kusumaningtyas, A. R., \& Mujiasih, E. (2016). Hubungan Antara Pengetahuan Produk dengan Intensi Membeli Smartphone Pada Karyawan PT. "X." Jurnal Empati, 5(2), 413-416.

Lupi, F. R., \& Nurdin, N. (2016). Analisis Strategi Pemasaran Dan Penjualan ECommerce Pada Tokopedia.Com. Jurnal Elektronik Sistem Informasi Dan Komputer, 2(1), 1-20.

Manuel, A.-D.-S., Ferran, C. M., Francisco, M. R., \& Alguacil, M. (2017). Online Sport Event Consumers: Attitude, e-Quality and e-Satisfaction. Journal of Theoretical and Applied Electronic Commerce Research, 1(1), 718.

Martinez, K. (2012). Predicting Purchase Intention For Private Sale Sites. Journal of Fashion Marketing and Management, 16(3), 1-20.

Meskaran, F., Ismail, Z., \& Shanmugam, B. (2013). Online Purchase Intention: Effects Of Trust And Security Perception. Australian Journal of Basic and Applied Sciences, 7(6), 307-315.

Obiedat, R. (2019). Impact of Online Consumer Reviews on Buying Intention of Consumers in UK: Need for Cognition as the Moderating Role. International Journal of Advanced Corporate Learning (IJAC), 6(2), 1-23.

Prasad, C. J. S., \& Aryasri, A. R. (2009). Determinants of Shopper Behaviour in Etailing: An Empirical Analysis. Paradigm Journal, 13(1), 73-83.

Shin, J. I., Chung, K. H., SinOh, J., \& Lee, C. W. (2014). The Effect Of Site Quality On Repurchase Intention In Internet Shopping Through Mediating Variables: The Case Of University Students In South Korea. International Journal of Information Management, 33(3), 453-463.

Sugiarto. (2012). Analisis Pengaruh Trust In Online Store, Perceived Risk, Attitude Towards Online Purchasing Terhadap Minat Beli Konsumen Produk Fashion 
Di Surabaya. Jurnal Ekonomi Dan Bisnis, 1(1), 1-20.

Thamizhvanan, A., \& Xavier, M. . (2013). Determinants Of Customers' Online Purchase Intention: An Empirical Study In India. Journal Of Indian Business Research, 5(1), 17-32.

Tirtayani, I. G. A. (2018). the Effect of Perceived Website Quality, E-Satisfaction , and E -Trust Towards Online Repurchase Intention. International Journal of Economics, Commerce and Management, VI(10), 262-287.

Trisdayana, A., Suryani, A., \& Sudiksa, I. B. (2018). Pengaruh Sikap Dan Norma Subjektif Terhadap Niat Beli Dan Keputusan Pembelian. E-Jurnal Manajemen Unud, 7(3), 1452-1480.

Trisna, E., \& Sefnedi. (2018). Factors Affecting Online Purchasing Intention : the Role of Attitude As Mediator. International Journal for Business and Societyournal of Economics, Commerce and Management, 6(5), 301-310.

Wani, T. A., Ali, S. W., \& Farooq, T. (2016). Determinants of Online Purchase Intentions: A Study of Indian Buyers. Amity Journal of Management Research, 1(11), 94-109. Retrieved from http://amity.edu/UserFiles/admaa/233Paper 7.pdf

Ye, Q., \& Ma, B. (2018). Internet+ and Electronic Business in China: Innovation and Applications. Innovation and Applications, 1(1), 3 - 12.

Younus, S., Rasheed, F., \& Zia, A. (2015). Identifying the Factors Affecting Customer Purchase Intention. Journal of Food Science, 5(3), 307-321. https://doi.org/10.1111/j.1365-2621.1940.tb17194.x 